\title{
Efektivitas Model Pembelajaran Problem-Based Learning dan Think Pair Share Berbantuan Geogebra Terhadap Kemampuan Pemecahan Masalah Matematis
}

\author{
Sutrisno $^{1 *}$, Nita Zuliyawati ${ }^{2}$, Rina Dwi Setyawati ${ }^{3}$ \\ 1,2,3 Universitas PGRI Semarang \\ *sutrisnojr@upgris.ac.id
}

Diterima: Agustus 2019. Disetujui: Desember 2019. Dipublikasikan: Januari 2020.

\begin{abstract}
ABSTRAK
Penelitian ini dilatar belakangi dengan pentingnya kemampuan pemecahan masalah matematis siswa. Tujuan penelitian ini untuk mengetahui efektivitas model Problem Based Learning dan model Cooperative Learning tipe Think Pair Share berbantuan geogebra. Jenis penelitian yang digunakan adalah penelitian eksperimen. Metode pengumpulan data terdiri dari dokumentasi, tes, dan observasi. Analisis data dalam penelitian ini digunakan analisis variansi, regresi, dan uji proporsi. Hasil penelitian ini menunjukkan bahwa siswa yang mendapat model PBL berbantuan geogebra memiliki kemampuan pemecahan masalah matematis sama dengan siswa yang mendapat model TPS berbantuan geogebra, dan kedua model pembelajaran tersebut menghasilkan kemampuan pemecahan masalah matematis siswa lebih baik daripada model pembelajaran konvensional. Hasil penelitian juga menunjukkan bahwa pada model PBL dan TPS berbantuan geogebra, terdapat pengaruh keaktifan belajar siswa dengan kemampuan pemecahan masalah matematisnya. Model PBL dan TPS berbantuan geogebra juga menghasilkan kemampuan pemecahan masalah yang memenuhi ketuntasan klasikal.
\end{abstract}

Kata kunci: Problem Based Learning, Think Pair Share, kemampuan pemecahan masalah matematis.

\section{ABSTRACT}

This research is motivated by the importance of students' mathematical problem solving abilities. The purpose of this study was to determine the effectiveness of the Problem Based Learning model and the Cooperative Learning model Think Pair Share type assisted by geogebra. The type of research used is experimental research. Data collection methods consist of documentation, testing, and observation. Data analysis in this study used analysis of variance, regression, and proportion test. The results of this study indicate that students who get geogebra-assisted PBL models have the same mathematical problem solving abilities as students who get geogebra-assisted TPS models, and both of these learning models produce students' mathematical problem-solving abilities better than conventional learning models. The results also showed that in the PBL and TPS models assisted by geogebra, there was an influence on students' learning activeness with their mathematical problem solving abilities. The geogebra-assisted PBL and TPS models also produce problem-solving abilities that meet classical completeness.

Keywords: Problem Based Learning, Think Pair Share, mathematical problem solving abilities.

How to Cite: Sutrisno, Zuliyawati, N., \& Setyawati, R. D. (2020). Efektivitas Model Pembelajaran Problem-Based Learning dan Think Pair Share Berbantuan Geogebra Terhadap Kemampuan Pemecahan Masalah Matematis. Journal of Medives: Journal of Mathematics Education IKIP Veteran Semarang, 4(1), $1-9$. 


\section{PENDAHULUAN}

Matematika adalah salah satu mata pelajaran yang memegang peranan sangat penting dalam pendidikan. Menurut Ismail (dalam Ali \& Rarini, 2014) matematika adalah ilmu yang membahas angka-angka dan perhitungannya, membahas masalah-masalah numerik, mengenai kuantitas dan besaran, mempelajari hubungan pola, bentuk dan struktur, sarana berpikir, kumpulan sistem, struktur dan alat. Depdiknas (2006) telah menyatakan bahwa tujuan pembelajaran matematika adalah agar siswa mempunyai kemampuan untuk memahami konsep matematika, menggunakan penalaran, memecahkan masalah, mengomunikasikan gagasan dengan simbol, tabel, diagram, atau media lain untuk memperjelas keadaan atau masalah serta memiliki sikap menghargai kegunaan matematika dalam kehidupan. Untuk mencapai tujuan pembelajaran matematika, salah satu kemampuan yang harus dikuasai siswa adalah kemampuan pemecahan masalah matematis. Muchlis (2012) mengatakan bahwa pemecahan masalah merupakan bentuk pembelajaran yang dapat menciptakan ide baru dan menggunakan aturan-aturan yang telah dipelajari terdahulu untuk membuat formulasi pemecahan masalah.

Dalam kurikulum yang berlaku di Indonesia saat ini yakni Kurikulum 2013, pentingnya kemampuan pemecahan masalah terlihat pada kompetensi dasar yang dimuat dalam standar isi pada Permendikbud Nomor 64 Tahun 2013. Kompetensi dasar tersebut menyebutkan bahwa siswa diharapkan dapat menunjukkan sikap logis, kritis, analitis, cermat dan teliti, bertanggung jawab, responsif, dan tidak mudah menyerah dalam memecahkan masalah (Kemendikbud, 2013).

Berdasarkan uraian di atas menyebutkan bahwa pemecahan masalah merupakan salah satu bagian yang penting dalam pembelajaran matematika. Namun, kenyataannya kemampuan pemecahan masalah matematika siswa masih rendah, hal tersebut dapat dilihat dari hasil Ujian Nasional (UN) siswa pada tiga tahun terakhir. Untuk perbandingan nilai UN bisa dilihat pada Tabel 1.

Tabel 1. Nilai Ujian Nasional SMP N 1 Karanganyar pada Tahun Pelajaran 2015-2017

\begin{tabular}{clccc}
\hline \multirow{2}{*}{ No } & \multirow{2}{*}{ Mata Pelajaran } & \multicolumn{3}{c}{ Tahun Pelajaran } \\
& & 2015 & 2016 & 2017 \\
\hline 1 & Bahasa Indonesia & 67,14 & 63,83 & 61,89 \\
2 & Bahasa Inggris & 43,88 & 40,55 & 39,41 \\
3 & Matematika & 36,96 & 34,42 & 42,92 \\
4 & IPA & 42,77 & 41,59 & 46,39 \\
\hline \multicolumn{4}{l}{ Sumber: https://puspendik.kemdikbud. go.id/hasil-un/ }
\end{tabular}

Capaian pembelajaran matematika SMP N 1 Karanganyar Demak pada tahun 2015 adalah 36,96 sementara pada tahun 2016 turun menjadi 34,42. Mata pelajaran matematika juga memiliki nilai terendah dibanding mata pelajaran lainnya.

Rendahnya kemampuan pemecahan masalah matematika yang tercermin dalam rendahnya nilai Ujian Nasional, dimungkinkan disebabkan oleh model pembelajaran yang diterapkan guru. Maka salah satu cara yang dapat dilakukan untuk mengatasi permasalahan tersebut, diperlukan suatu model 
pembelajaran yang lebih variatif dan inovatif. Salah satu model pembelajaran yang dapat meningkatkan kemampuan pemecahan masalah matematis siswa adalah pembelajaran dengan model Problem Based Learning (PBL). Menurut Suprijono (2016), pembelajaran berbasis masalah adalah pembelajaran yang menyuguhkan berbagai situasi permasalahan yang autentik dan bermakna kepada siswa agar mereka menyelidikinya. Pembelajaran dengan model PBL adalah pendekatan pengajaran yang memberikan tantangan bagi siswa untuk mencari solusi dari permasalahan dunia nyata secara individu maupun kelompok, sehingga dapat memberikan kondisi pembelajaran yang aktif kepada siswa. Melalui keterlibatan aktif pada siswa, maka diharapkan kemampuan pemecahan masalah siswa akan dapat terlatih dengan baik.

Model pembelajaran lain yang dapat dijadikan alternatif guru adalah model pembelajaran Think Pair Share (TPS). Model ini merupakan jenis pembelajaran kooperatif yang dirancang untuk mempengaruhi pola interaksi siswa. Hasil penelitian Bubin (dalam (Husna \& Fatimah, 2013) menunjukkan bahwa pembelajaran dengan menggunakan model pembelajaran TPS dapat meningkatkan kemampuan pemecahan masalah matematis siswa. Model pembelajaran TPS memberikan siswa kesempatan untuk bekerja sendiri dalam memecahkan masalah yang diberikan guru serta kesempatan untuk bekerja sama di dalam kelompok. Model pembelajaran TPS ini menghendaki siswa untuk belajar saling membantu dalam kelompok kecil yang heterogen (Zulfah, 2017).

Kedua model tersebut dipadukan dengan media pembelajaran berbasis software, dan dipilih Geogebra sebagai alat bantu pada proses pembelajaran matematika, dengan pertimbangan bahwa Geogebra merupakan software yang mudah digunakan dan freeware. Geogebra merupakan software yang digunakan untuk geometri, aljabar, dan kalkulus secara geometri (Ekawati, 2016). Geogebra adalah sistem geometri dinamik, yang dapat melakukan konstruksi dengan titik, vektor, ruas garis, irisan kerucut, begitu juga dengan fungsi, dan mengubah hasil konstruksi selanjutnya.

Rumusan masalah dalam penelitian ini adalah apakah kemampuan pemecahan masalah matematis siswa antara pembelajaran yang menggunakan model Problem Based Learning (PBL) berbantuan Geogebra lebih baik dibandingkan dengan model pembelajaran Think Pair Share (TPS) berbantuan Geogebra?; (2) Apakah kemampuan pemecahan masalah matematis siswa pada model pembelajaran Problem Based Learning (PBL) berbantuan Geogebra lebih baik dibandingkan dengan model pembelajaran konvensional?; (3) Apakah kemampuan pemecahan masalah matematis siswa pada model pembelajaran Think Pair Share (TPS) berbantuan Geogebra lebih baik dibandingkan dengan model pembelajaran konvensional?; Apakah terdapat pengaruh keaktifan belajar siswa pada pembelajaran menggunakan model pembelajaran Problem Based Learning (PBL) 
berbantuan Geogebra dan model pembelajaran Think Pair Share (TPS) berbantuan Geogebra terhadap kemampuan pemecahan masalah matematis siswa?; (5) Apakah kemampuan pemecahan masalah matematis siswa yang mendapat model pembelajaran Problem Based Learning (PBL) berbantuan Geogebra dan model pembelajaran Think Pair Share (TPS) berbantuan Geogebra mencapai KKM?

\section{METODE PENELITIAN}

Penelitian ini dilakukan di kelas VIII SMP N 1 Karanganyar Demak pada bulan Mei Semester Genap Tahun Ajaran 2018/2019. Desain penelitian yang digunakan adalah pretest-posttest control group design, dengan teknik cluster random sampling, yaitu dengan mengambil tiga kelas secara acak dari populasi. Tiga kelas yang terpilih yaitu kelas VIII A dan VIII C sebagai kelas eksperimen dan kelas VIII D sebagai kelas kontrol. Pada analisis data awal telah diketahui bahwa semua kelas memiliki kemampuan awal (kemampuan pemecahan masalah matematis) yang sama.

Teknik pengumpulan data dalam penelitian ini adalah dokumentasi, tes, dan observasi. Instrumen yang digunakan dalam penelitian ini adalah tes kemampuan pemecahan masalah matematis siswa dan lembar observasi keaktifan siswa. Sebelum digunakan, tes divalidasi terlebih dahulu dan kemudian diujicobakan untuk mengetahui reliabilitas, tingkat kesukaran, dan daya pembeda. Berdasarkan analisis tes dan butirnya, didapat 6 butir tes terpilih yang digunakan untuk mengukur kemampuan pemecahan masalah matematis siswa. Analisis data dalam penelitian ini meliputi analisis variansi (ANAVA), regresi, dan uji proporsi.

\section{HASIL DAN PEMBAHASAN}

Analisis akhir dilakukan setelah diberikan perlakuan, hal ini dilakukan untuk menguji hipotesis dalam rangka penarikan kesimpulan untuk mencapai tujuan penelitian. Dalam analisis data akhir ini menggunakan data kemampuan pemecahan masalah matematis siswa setelah perlakuan. Sebelum uji anava harus dilakukan terlebih dahulu uji normalitas distribusi dan uji homogenitas variansi. Tabel 2 menampilkan uji normalitas distribusi kelas eksperimen 1 , kelas eksperimen 2, dan kelas kontrol.

Tabel 2. Uji Normalitas Distribusi

\begin{tabular}{lcccc}
\hline \multicolumn{1}{c}{ Kelas } & $\mathrm{n}$ & $L_{0}$ & $\mathrm{~L}_{\text {tabel }}$ & $\begin{array}{c}\text { Kesim- } \\
\text { pulan }\end{array}$ \\
\hline Eksperimen 1 & 28 & 0,115 & 0,167 & Normal \\
Eksperimen 2 & 26 & 0,149 & 0,173 & Normal \\
Kontrol & 26 & 0,171 & 0,173 & Normal \\
\hline
\end{tabular}

Berdasarkan Tabel 2 terlihat bahwa $\mathrm{L}_{0} \leq \mathrm{L}_{\text {tabel }}$ pada taraf signifikan $5 \%$ dan $\mathrm{n}_{1}=28, \mathrm{n}_{2}=26$, dan $\mathrm{n}_{3}=26$ baik untuk kelompok eksperimen 1 , eksperimen 2 dan kontrol berdistribusi normal.

Tabel 3. Uji Homogenitas Variansi

\begin{tabular}{ccc}
\hline Kelompok & $\mathrm{n}_{\mathrm{i}}$ & $\mathrm{si}^{2}$ \\
\hline Eksperimen 1 & 28 & 179,1 \\
Eksperimen 2 & 26 & 225,1 \\
Kontrol & 26 & 159,2 \\
$\mathrm{~B}$ & & 175,04 \\
$\chi^{2}$ hitung & & 0,7877 \\
$\chi^{2}$ tabel & & 5,9914 \\
\hline
\end{tabular}

Berdasarkan Tabel 3 diperoleh $\chi_{\text {hitung }}^{2}=0,78$. Untuk $\alpha=5 \%, \mathrm{dk}=2$, 
diperoleh $\chi_{\text {tabel }}^{2}=5,99$. Karena $\chi_{\text {hitung }}^{2} \leq$ $\chi_{\text {tabel }}^{2}$ yaitu $0,78<5,99$ maka $\mathrm{H}_{0}$ diterima, yang berarti ketiga kelas mempunyai variansi yang sama atau homogen.

Untuk mengetahui ada atau tidaknya perbedaan kemampuan pemecahan masalah matematis siswa jika pembelajaran matematika dengan menggunakan model PBL berbantuan geogebra dan model pembelajaran TPS berbantuan geogebra maka dilakukan uji anava satu arah. Berikut deskripsi data pada penelitian ini akan disajikan pada Tabel 4.

\begin{tabular}{cccc}
\multicolumn{4}{c}{ Tabel 4. Deskripsi Data } \\
\hline $\begin{array}{c}\text { Model } \\
\text { Pembelajaran }\end{array}$ & $\mathrm{n}$ & $\overline{\mathrm{X}}$ & $\mathrm{s}^{2}$ \\
\hline PBL & 28 & 73,9 & 179,1 \\
TPS & 26 & 72,5 & 225,1 \\
Konvensional & 26 & 56,4 & 159,2 \\
\hline
\end{tabular}

Tabel 5. Rangkuman Analisis Variansi

\begin{tabular}{crrrr}
\hline $\begin{array}{c}\text { Sumber } \\
\text { Variasi }\end{array}$ & JK & dk & RK & F \\
\hline Perlakuan & 4968,56 & 2 & 2484,2 & 13,24 \\
Galat & 14446,81 & 77 & 187,6 & \\
Total & 19415,38 & 79 & \multicolumn{2}{c}{-} \\
\hline
\end{tabular}

\begin{tabular}{cccc}
\multicolumn{4}{c}{ Tabel 6. Uji Scheffe' } \\
\hline $\mathrm{H}_{0}$ & $\mathrm{RKG}$ & $\mathrm{F}_{\text {hitung }}$ & Keputusan \\
\hline$\mu_{1}=\mu_{3}$ & 187,62 & 21,92 & $\mathrm{H}_{0}$ ditolak \\
$\mu_{2}=\mu_{3}$ & 187,62 & 17,82 & $\mathrm{H}_{0}$ ditolak \\
$\mu_{1}=\mu_{2}$ & 187,62 & 0,14 & $\mathrm{H}_{0}$ diterima \\
\hline $\mathrm{F}_{\text {tabel }}$ & \multicolumn{3}{c}{3,12} \\
\hline $2 \mathrm{~F}_{\text {tabel }}$ & \multicolumn{3}{c}{6,24} \\
\hline
\end{tabular}

Berdasarkan Tabel 5 diperoleh $\mathrm{F}_{\text {hitung }}=13,24$. Dari tabel distribusi $\mathrm{F}$ untuk $\alpha=5 \%$ dengan $\mathrm{dk}$ pembilang 2 dan $\mathrm{dk}$ penyebut 77 diperoleh $\mathrm{F}_{\text {tabel }}=$ 3,12 (interpolasi). Karena $\mathrm{F}_{\text {hitung }}>$ $\mathrm{F}_{\text {tabel }}$ yaitu $13,24>3,12$, maka $\mathrm{H}_{0}$ ditolak. Sehingga dapat disimpulkan bahwa terdapat perbedaan kemampuan pemecahan masalah matematis yang diberi model PBL berbantuan geogebra, model pembelajaran TPS berbantuan geogebra, dan model konvensional.

Untuk hipotesis 1, 2, dan 3 dilakukan dengan uji Scheffe' dimana diperoleh perhitungan yang terangkum pada Tabel 6. Dari Tabel 6 diperoleh $\mathrm{F}_{\text {hitung }}$ sebagai berikut. $\mathrm{F}_{1-2}=0,149$; $F_{1-3}=21,92 ; F_{2-3}=17,82$. Harga $F_{\text {hitung }}$ tersebut selanjutnya dibandingkan dengan $(\mathrm{k}-1) \mathrm{F}_{\text {tabel }}$, dengan taraf signifikan $\alpha=5 \%$ maka harga $(\mathrm{k}-1) \mathrm{F}_{\alpha ;(\mathrm{k}-1),(\mathrm{N}-\mathrm{k})}=(3-1) \mathrm{F}_{0,05 ;(3-1),(80-3)}$ $=2 \mathrm{~F}_{0,05 ;(2),(77)}=6,24$ ternyata untuk hipotesis 1 nilai $\mathrm{F}_{\text {hitung }}<(\mathrm{k}-1) \mathrm{F}_{\text {tabel }}$ yaitu $0,149<6,24$ maka $\mathrm{H}_{0}$ diterima sehingga tidak terdapat perbedaan kemampuan pemecahan masalah matematis siswa yang menggunakan model PBL berbantuan geogebra dengan menggunakan model pembelajaran TPS berbantuan geogebra. Hal tersebut sesuai dengan hasil penelitian Siregar \& Syafari (2017) yang menyatakan bahwa model PBL dan model pembelajaran kooperatif tipe TPS dapat meningkatkan kemampuan pemecahan masalah matematis siswa.

Untuk hipotesis 2 nilai $F_{\text {hitung }}>$ $(k-1) F_{\text {tabel }}$ yaitu $21,92>6,24$ maka $\mathrm{H}_{0}$ ditolak sehingga terdapat perbedaan kemampuan pemecahan masalah matematis siswa yang menggunakan model PBL berbantuan geogebra dengan menggunakan model pembelajaran konvensional. Dilihat dari hasil rata-rata kemampuan pemecahan masalah matematis $\overline{X_{1}}=73,92$ dan $\quad \overline{X_{3}}=56,46$ maka $\overline{X_{1}}>\overline{X_{3}}$ sehingga dapat digeneralisasikan bahwa $\mu_{1}>\mu_{3}$ atau 
dapat dikatakan bahwa kemampuan pemecahan masalah matematis dengan model PBL berbantuan geogebra lebih baik dari pada model pembelajaran konvensional. Hasil penelitian ini didukung oleh penelitian yang dilakukan Sari (2018), Hafiza (2018), dan Delyana, F, \& M.P (2017) yang mengatakan bahwa kemampuan pemecahan masalah matematis siswa pada model PBL lebih baik dari pada kemampuan pemecahan masalah matematis siswa pada model konvensional. Hasil penelitian lainnya juga telah mengungkapkan bahwa kemampuan berpikir kreatif siswa dalam matematika yang diajarkan dengan model pembelajaran Problem Based Learning (PBL) lebih baik dari model pembelajaran konvensional (Malasari, Rasiman, \& Sutrisno, 2019).

Untuk hipotesis 3 nilai $\mathrm{F}_{\text {hitung }}>(\mathrm{k}-1) \mathrm{F}_{\text {tabel }}$ yaitu $17,82>6,24$ maka $\mathrm{H}_{0}$ ditolak sehingga terdapat perbedaan kemampuan pemecahan masalah matematis siswa yang menggunakan model TPS berbantuan geogebra dengan menggunakan model pembelajaran konvensional. Dilihat dari hasil rata-rata kemampuan pemecahan masalah matematis $\overline{X_{2}}=72,5$ dan $\overline{X_{3}}=56,46$ maka $\overline{X_{2}}>\overline{X_{3}}$ sehingga dapat digeneralisasikan bahwa $\mu_{2}>\mu_{3}$ atau dapat dikatakan bahwa kemampuan pemecahan msalah matematis siswa dengan model pembelajaran TPS berbantuan geogebra lebih baik dari pada model pembelajaran konvensional. Hal tersebut sejalan dengan hasil penelitian Muhlisin, Asikin, \& Kartono (2013) dengan menggunakan model pembelajaran Think Pair Share menunjukkan bahwa pembelajaran yang menggunakan model Think Pair Share lebih efektif dari pada model pembelajaran konvensional. Hasil penelitian Zulfah (2017) menyatakan bahwa ada perbedaan kemampuan pemecahan masalah matematis siswa yang menerapkan model pembelajaran Think Pair Share dengan pendekatan Heuristik dengan siswa yang menerapkan model pembelajaran konvensional. Hasil penelitian Sujana (2017) menyatakan bahwa kemampuan pemecahan masalah siswa yang menggunakan model pembelajaran Think Pair Share lebih baik dibandingkan dengan siswa yang menggunakan model pembelajaran ceramah.

Untuk uji hipotesis 4 dengan uji regresi linear sederhana. Uji regresi ini digunakan untuk mengetahui pengaruh keaktifan siswa terhadap kemampuan pemecahan masalah matematis siswa yang mendapat model PBL dan TPS berbantuan geogebra. Pada kelas eksperimen 1 diperoleh persamaan $\widehat{Y}=7,101+0,956 X$ dan dari perhitungan determinasi diperoleh $\mathrm{r}^{2}=0,98$ sehingga dalam hal ini dapat dijelaskan bahwa $98 \%$ nilai-nilai kemampuan pemecahan masalah matematis model PBL $\left(\mathrm{Y}_{1}\right)$ telah menyumbangkan terhadap keaktifan siswa $\left(\mathrm{X}_{1}\right)$. Hal tersebut sejalan dengan hasil penelitian dari Widyanti (2015) yang menyatakan bahwa pembelajaran dengan model PBL dapat meningkatkan keaktifan belajar dan kemampuan pemecahan masalah matematika. Pada kelas eksperimen 2 diperoleh persamaan garis regresi $\widehat{Y}=38,156+0,609 \mathrm{X}$ dan dari perhitungan determinasi diperoleh $\mathrm{r}^{2}=0,99$ sehingga dalam hal ini dapat dijelaskan bahwa 99\% nilai-nilai kemampuan 
pemecahan masalah matematis model pembelajaran tipe TPS $\left(\mathrm{Y}_{1}\right)$ telah menyumbangkan terhadap keaktifan siswa $\left(\mathrm{X}_{1}\right)$. Hal tersebut sejalan dengan penelitian Raditya, Kristiantari, \& Suara (2015), tentang model Think Pair Share berpengaruh pada keaktifan yaitu adanya perbedaan yang signifikan, ini menunjukkan bahwa pengaruh model pembelajaran TPS sangat berpengaruh terhadap hasil belajar siswa dibandingkan dengan model pembelajaran konvensional. Hasil penelitian Rahayu (2014) menyatakan bahwa model pembelajaran Think Pair Share dapat meningkatkan keaktifan belajar dan hasil belajar siswa kelas VII F SMP Negeri 25 Purworejo.

Untuk uji hipotesis 5 dengan uji proporsi pihak kiri. Uji ini digunakan untuk mengetahui bahwa kemampuan pemecahan masalah matematika siswa yang mendapatkan model Problem Based Learning dan Think Pair Share mencapai KKM. Untuk kelas eksperimen 1 diperoleh $Z_{\text {hitung }}=0,98$. Dengan $\alpha=5 \%$ maka $Z_{0,05}=1,645$ dan untuk daerah kritisnya yaitu $\mathrm{DK}=$ $\left\{\mathrm{Z} \mid \mathrm{Z}<-\mathrm{Z}_{\alpha}\right\}=\{\mathrm{Z} \mid \mathrm{Z}<-1,645\} . \quad$ Karena $Z_{\text {hitung }} \notin \mathrm{DK}$ maka $\mathrm{H}_{0}$ diterima sehingga proporsi siswa yang tuntas pada model PBL berbantuan geogebra mencapai KKM klasikal. Hal ini sejalan dengan pendapat Mubaid, Sutrisno, \& Endahwuri (2019) yang menyatakan bahwa kemampuan pemahaman konsep matematis siswa yang mendapat model pembelajaran PBL berbantuan Geogebra mencapai KKM. Untuk kelas eksperimen 2 diperoleh $Z_{\text {hitung }}=0,34$. Dengan $\alpha=5 \%$ maka $Z_{0,05}=1,645$ dan untuk daerah kritisnya yaitu $\mathrm{DK}=\left\{\mathrm{Z} \mid \mathrm{Z}<-\mathrm{Z}_{\alpha}\right\}$. Karena $\mathrm{Z}_{\text {hitung }} \notin \mathrm{DK}$ maka $\mathrm{H}_{0}$ diterima sehingga proporsi siswa yang mendapat model pembelajaran TPS berbantuan geogebra mencapai KKM klasikal. Hal ini sesuai dengan pendapat Darojatil u'la, Murtono, \& Ulya (2018) yang menyatakan bahwa siswa yang memperoleh model pembelajaran TPS mendapat nilai ratarata tes kemampuan komunikasi matematis mencapai KKM.

\section{PENUTUP}

Berdasarkan hasil penelitian dan pembahasan maka dapat disimpulkan bahwa: (1) tidak terdapat perbedaan kemampuan pemecahan masalah matematis siswa antara pembelajaran yang menggunakan model PBL berbantuan Geogebra dengan model pembelajaran TPS berbantuan Geogebra, (2) kemampuan pemecahan masalah matematis siswa pada model pembelajaran PBL berbantuan Geogebra lebih baik dibandingkan dengan model pembelajaran konvensional, (3) kemampuan pemecahan masalah matematis siswa pada model pembelajaran TPS berbantuan Geogebra lebih baik dibandingkan dengan model pembelajaran konvensional, (4) terdapat pengaruh keaktifan belajar siswa terhadap kemampuan pemecahan masalah matematis pada model PBL dan TPS berbantuan Geogebra, serta (5) kemampuan pemecahan masalah matematis siswa yang mendapat model pembelajaran PBL dan TPS berbantuan Geogebra mencapai KKM. 
DAFTAR PUSTAKA

Ali, H., \& Rarini, M. (2014). Perencanaan dan Strategi Pembelajaran Matematika. Jakarta, PT. Raja Grafindo Persada.

Darojatil u'la, I., Murtono, M., \& Ulya, H. (2018). Efektivitas Model Pembelajaran Think-Pair-Share (TPS) Terhadap Kemampuan Komunikasi Matematis Siswa. ANARGYA: Jurnal Ilmiah Pendidikan Matematika, 1(1), 5158.

Delyana, H., F, R., \& M.P, Y. (2017). Penerapan Model Problem Based Learning Terhadap Kemampuan Pemecahan Masalah Matematis Siswa. Prosiding Seminar Nasional STKIP PGRI Sumatera Barat.

Ekawati, A. (2016). Penggunaan Software Geogebra dan Microsoft Mathematic dalam Pembelaran Matematika. Math Didactic: Jurnal Pendidikan Matematika, 2(3), 148-153.

Hafiza, N. (2018). Meningkatkan Kemampuan Pemecahan Masalah melalui Model Problem Based Learning pada Siswa SMP/MTsN (PhD Thesis). UIN Ar-Raniry Banda Aceh.

Husna, M., \& Fatimah, S. (2013). Peningkatan kemampuan pemecahan masalah dan Komunikasi matematis siswa Sekolah Menengah Pertama melalui model pembelajaran kooperatif tipe Think-pair-share (TPS). Jurnal Peluang, 1(2), 8192.
Kemendikbud. (2013). Permendikbud RI Nomor 64 Tahun 2013 tentang Standar Isi Pendidikan Dasar dan Menengah. Kemendikbud.

Malasari, E. Y. U., Rasiman, R., \& Sutrisno, S. (2019). EFEKTIVITAS MODEL PEMBELAJARAN PROBLEM BASED LEARNING DAN SCRAMBLE TERHADAP KEMAMPUAN BERPIKIR KREATIF SISWA. Media Penelitian Pendidikan: Jurnal Penelitian dalam Bidang Pendidikan dan Pengajaran, 12(2), 169-176.

Mubaid, A., Sutrisno, S., \& Endahwuri, D. (2019). EFEKTIFITAS MODEL PEMBELAJARAN PROBLEM BASED LEARNING DAN MODEL PEMBELAJARAN LEARNING CYCLE 5E BERBANTUAN GEOGEBRA TERHADAP KEMAMPUAN PEMAHAMAN KONSEP MATEMATIS SISWA KELAS XI SMK ANTONIUS SEMARANG. Senatik, 400-407.

Muchlis, E. E. (2012). Pengaruh pendekatan pendidikan matematika realistik indonesia (PMRI) terhadap perkembangan kemampuan pemecahan masalah siswa kelas II SD Kartika 1.10 Padang. EXACTA, 10(2), 136-139.

Muhlisin, M., Asikin, M., \& Kartono, K. (2013). KEEFEKTIFAN PEMBELAJARAN MODEL TPS BERBANTUAN GEOMETER'S SCETCHPAD PADA PENCAPAIAN KEMAMPUAN PEMECAHAN MASALAH. Unnes Journal of Mathematics Education, 2(1). 
Raditya, I. W., Kristiantari, M. R., \& Suara, I. M. (2015). Pengaruh Model Pembelajaran Kooperatif Tipe Think Pair Share (TPS) Terhadap Hasil Belajar IPA Siswa Kelas VI SD Gugus Letda Made Putra Kecamatan Denpasar Utara Tahun Ajaran 2014/2015. MIMBAR PGSD Undiksha, 3(1).

Rahayu, S. (2014). Peningkatan Keaktifan Belajar Siswa dengan Model Pembelajaran Think Pair Share. Ekuivalen-Pendidikan Matematika, 12(2), 151-156.

Sari, D. N. (2018). PENGARUH MODEL PROBLEM BASED LEARNING TERHADAP KEMAMPUAN

PEMECAHANMASALAH PESERTA DIDIK. Jurnal Edukasi Dan Penelitian Matematika, 7(1). Diambil dari http://ejournal.unp.ac.id/students/i ndex.php/pmat/article/view/5544

Siregar, N. H., \& Syafari. (2017, Mei 6). KEMAMPUAN PEMECAHAN MASALAH MATEMATIS SISWA DALAM PEMBELAJARAN MATEMATIKA MENGGUNAKAN MODEL PEMBELAJARAN PBL DAN TPS. Dipresentasikan pada Seminar Nasional Matematika (SEMNASTIKA) 2017, Medan. Diambil dari http://digilib.unimed.ac.id/26922/
Sujana, A. (2017). PENGARUH MODEL PEMBELAJARAN KOOPERATIF TIPE THINK PAIR SHARE (TPS) TERHADAP PENINGKATAN

KEMAMPUAN PEMECAHAN MASALAH MATEMATIKA SISWA. Symmetry: Pasundan Journal of Research in Mathematics Learning and Education, 2(1), 43-52.

Suprijono, A. (2016). Model-model pembelajaran emansipatoris. Yogyakarta: Pustaka Pelajar.

Widyanti, S. (2015). UPAYA MENINGKATKAN

KEAKTIFAN BELAJAR DAN KEMAMPUAN PEMECAHAN MASALAH MATEMATIKA MELALUI MODEL PROBLEM BASED LEARNING SISWA KELAS VIID SMP NEGERI 3 GAMPING SLEMAN. Universitas PGRI Yogyakarta.

Zulfah, Z. (2017). Pengaruh Penerapan Model Pembelajaran Kooperatif Tipe Think Pair Share Dengan Pendekatan Heuristik Terhadap Kemampuan Pemecahan Masalah Matematis Siswa Mts Negeri Naumbai Kecamatan Kampar. Jurnal Cendekia: Jurnal Pendidikan Matematika, 1(2), 112. 